\title{
ZRÓŻNICOWANIE POPULACJI GŁAZÓW EOLIZOWANYCH W RÓŻNOWIEKOWYCH STREFACH PERYGLACJALNYCH POLSKI ZACHODNIEJ
}

\author{
BARBARA ANTCZAK-GÓRKA \\ Zaklad Geomorfologii, Instytut Geoekologii i Geoinformacji, \\ Uniwersytet im. Adama Mickiewicza w Poznaniu
}

\begin{abstract}
The article presents the results of statistical analysis performed on various populations of wind-polished boulders in the lowland part of Western Poland. The populations were studied in three zones connected with stages of retreat of the Last Glaciation, both in the foreland and hinterland of each of the zones, to accommodate differences in climatic conditions and genetic types of substratum. Those factors influenced the original population of stones that could then be transformed by the wind. It was found that wind-polished boulders were a common occurrence in the study area, whether lying on the surface or as stone horizons underlying aeolian cover sands. Spatial differences among those populations are due to variations of climatic conditions accompanying the successive stages of retreat of the last inland ice.
\end{abstract}

Keywords: Western Poland, periglacial zones, eolized boulders

\section{WPROWADZENIE}

Głazy rzeźbione przez wiatr zostały ukształtowane w warunkach klimatu suchego i zimnego określanego przez Kozarskiego (1995) jako pustynia arktyczna. Warunki takie są typowe dla okresu deglacjacji, która na badanym obszarze odbywała się w trzech fazach (leszczyńskiej, poznańskiej i pomorskiej). Dlatego można mówić o trzech różnowiekowych strefach peryglacjalnych. Dystans czasowy pomiędzy tymi strefami jest różny, gdyż różnica pomiędzy fazą leszczyńską i poznańską to tylko 1200 lat, natomiast pomiędzy fazą poznańską i pomorską - 2600 lat (Kozarski 1995; Rotnicki, Borówka 1991, 1994). Również inne są relacje przestrzenne między tymi fazami, gdyż odległość pomiędzy morenami czołowymi fazy leszczyńskiej i poznańskiej jest mniejsza niż między tymi morenami fazy poznańskiej i pomorskiej. Należy więc przypuszczać, że zarówno czynnik czasowy, jak i przestrzenny znalazł odbicie w intensywności procesów typowych dla strefy peryglacjalnej. Chcąc dokonać oszacowania tej zmienności, zastosowano zestaw prostych metod statystycznych. 


\section{ZMIENNOŚĆ POPULACJI GŁAZÓW EOLIZOWANYCH W UKŁADZIE POŁUDNIKOWYM W POLSCE ZACHODNIEJ}

Jako zbiór próbek losowych potraktowano procentowy udział różnych typów głazów eolizowanych na polach testowych. Według Gergory'ego (1976) i Norcliffe'a (1986) związek, jaki uzyskujemy pomiędzy parametrami z próbki (w tym przypadku pola testowego) zależy od wielkości próbki i metody jej otrzymywania. Dla oceny wiarygodności otrzymanych parametrów z próbek obliczono dla nich błąd standardowy, zakładając, że średnia z próbek leży w granicach trzech odchyleń standardowych z prawdopodobieństwem 99,7\%. Opierając się na tej wartości i wartości najlepszej oceny odchylenia standardowego, obliczono jaka powinna być minimalna wielkość próbki, aby spełniała ona założenia o prawdopodobieństwie prawdziwej średniej. Wyniki tego oszacowania dla kolejnych badanych stref morfologicznych przedstawiono w tabeli 1 .

Tabela 1. Szacowana wielkość próbek minimalnych

Table 1. Estimated minimum size of samples

\begin{tabular}{lcc}
\hline \multirow{2}{*}{ Obszar badań } & \multicolumn{2}{c}{ Wielkość próbki minimalnej } \\
\cline { 2 - 3 } & wysoczyzny morenowe & sandry \\
\hline Przedpole fazy leszczyńskiej & $77 \pm 6$ & $76 \pm 7$ \\
Zaplecze fazy leszczyńskiej & $72 \pm 5$ & $69 \pm 7$ \\
Przedpole fazy poznańskiej & $76 \pm 10$ & $83 \pm 11$ \\
Zaplecze fazy poznańskiej & $85 \pm 8$ & $82 \pm 9$ \\
Przedpole fazy pomorskiej & $79 \pm 6$ & $82 \pm 8$ \\
Zaplecze fazy pomorskiej & $77 \pm 8$ & $80 \pm 9$ \\
\hline
\end{tabular}

Do dalszych opracowań statystycznych stosowano jedynie te próbki, których wielkość znalazła się w granicach oszacowanych na podstawie przedstawionego materiału terenowego. Najmniejsze wartości oszacowanych próbek minimalnych w najstarszej z badanych stref morfologicznych wynikają z faktu, iż w strefie tej populacje graniaków są najbardziej liczne i najsłabiej zróżnicowane w obrębie badanych stanowisk.

Dane dotyczące częstotliwości występowania graniaków i eologliptolitów przedstawiono w procentach jako udział badanych zbiorów w całkowitej populacji klastów. Natomiast dane dotyczące typów graniaków informują o procentowym udziale danego typu graniaków w całym ich zbiorze, a nie odnoszą się do całej populacji głazów z pola testowego. Pola testowe, na których nie stwierdzono występowania głazów eolizowanych, otrzymały wartość zerową. W ten sam sposób przeliczano udział poszczególnych frakcji graniaków. Na podstawie tych danych dokonywano dalszych opracowań statystycznych, oczywiście poza 
wartościami współczynników korelacji, gdzie należy operować danymi oryginalnymi. Według Gergory'ego (1986) nie budzi zastrzeżeń zastosowanie takich danych do analizy statystycznej w zakresie zmienności populacji, a za jej najprostszy miernik uznaje on odchylenie standardowe. Dlatego w pierwszej fazie zastosowano ten miernik.

Jak stwierdzono, najprostszą miarą zmienności populacji jest odchylenie standardowe, gdyż informuje ono o różnicy pomiędzy wielkościami rzeczywistymi badanych zmiennych i wartością średnią. Dla wszystkich analizowanych stref obliczono średnią wielkość tego współczynnika i w ten sposób uzyskano obraz zmienności różnowiekowych populacji graniaków (tab. 2).

Tabela 2. Odchylenie standardowe dla różnowiekowych populacji głazów eolizowanych

Table 2. Standard deviation for populations of wind-polished stones of various ages

\begin{tabular}{|c|c|c|c|}
\hline \multirow[b]{2}{*}{ Strefa morfologiczna } & \multirow[b]{2}{*}{$\begin{array}{l}\text { Liczba pól } \\
\text { testowych }\end{array}$} & \multicolumn{2}{|c|}{ Odchylenie standardowe } \\
\hline & & $\begin{array}{c}\text { wysoczyzny more- } \\
\text { nowe }\end{array}$ & sandry \\
\hline Przedpole fazy leszczyńskiej & 173 & 1,91 & 3,60 \\
\hline Zaplecze fazy leszczyńskiej & 153 & 1,71 & 3,01 \\
\hline Przedpole fazy poznańskiej & 149 & 2,29 & 4,12 \\
\hline Zaplecze fazy poznańskiej & 151 & 3,02 & 3,96 \\
\hline Przedpole fazy pomorskiej & 99 & 2,94 & 3,70 \\
\hline Zaplecze fazy pomorskiej & 89 & 2,08 & 2,88 \\
\hline
\end{tabular}

Z zestawienia wynika, że większym zróżnicowaniem cechują się populacje graniaków na powierzchniach akumulacji fluwioglacjalnej we wszystkich badanych strefach morfologicznych. Najmniej zróżnicowane są populacje graniaków fazy leszczyńskiej, co wynika z długotrwałego zaawansowanego modelowania eolicznego tych głazów. Największe wartości wskaźnik ten osiaga dla zaplecza fazy poznańskiej i pomorskiej, co świadczy o dużym zróżnicowaniu badanych populacji, szczególnie na powierzchniach sandrowych.

Mniejsze wartości odchylenia standardowego dla strefy przedpola i zaplecza fazy pomorskiej wynikają z faktu, że dominują w nich pola testowe, na których odnotowano niewielkie populacje eologliptolitów oraz pola testowe, na których brak takich głazów. Nie udało się stwierdzić wyraźnej południkowej zmienności tego wskaźnika dla wszystkich analizowanych stref, chociaż generalnie istnieje tendencja do jego wzrostu w kierunku północnym, w więc większego zróżnicowania badanych populacji w tym kierunku.

Analogicznych porównań dokonano dla eoligliptolitów występujących na 
poziomach terasowych w pradolinach funkcjonujących podczas kolejnych faz ostatniego zlodowacenia (tab. 3).

Tabela 3. Zmienność populacji eologliptolitów na poziomach terasowych w pradolinach

Table 3. Standard deviations for populations of wind-polished stones on pradolina terraces

\begin{tabular}{lcc}
\hline \multirow{2}{*}{ Pradolina } & \multicolumn{2}{c}{ Odchylenie standardowe } \\
\cline { 2 - 3 } & eologliptolity & graniaki \\
\hline Baryczy & 2,73 & 2,25 \\
Warszawsko-Berlińska & 3,80 & 3,55 \\
Toruńsko-Eberswaldzka & 4,01 & 3,93 \\
\hline
\end{tabular}

Z porównania przedstawionego w tabeli 3 wynika, że zmienność populacji zarówno kamieni eolizowanych, jak i graniaków jest znaczna. Najbardziej zwarte, o najmniejszej zmienności, są populacje z najstarszego obszaru pradolinnego, a więc Pradoliny Baryczy, a im bardziej na północ zlokalizowane były stanowiska badawcze w pradolinach, tym zmienność badanych populacji była większa. Takiej prawidłowości nie udało się stwierdzić, analizując głazy eolizowane występujące na powierzchniach akumulacji glacjalnej i fluwioglacjalnej, co być może wynika z użytkowania pól przez człowieka.

Istotnym okazało się również obliczenie średniej liczby klastów eolizowanych występujących na jednym metrze kwadratowym pola testowego. $\mathrm{Na}$ początkowym etapie opracowania zrezygnowano z tego prostego wskaźnika, gdyż prowadziłby on do pojawiania się wartości ułamkowych, jak wszystkie wartości byłby inny niż wartość rzeczywista. Na końcowym etapie opracowania zastosowano również tę miarę zmienności, a wskaźnik uzyskany w ten sposób nazwano wskaźnikiem wentyfikacji. Ponieważ w literaturze jako wentyfikację określa się proces formowania graniaków, obliczono jedynie średnią częstotliwość pojawiania się graniaków w kolejnych strefach morfologicznych ostatniego zlodowacenia. Zmienność tego wskaźnika w układzie południkowym przedstawiono za pomocą tabeli 4 .

Ten wskaźnik okazał się również czułym na zmienność południkową częstotliwości występowania eologliptolitów. Tak jak w analizowanych wartościach procentowych, tak i w tych wartościach potwierdziła się prawidłowość, że więcej głazów eolizowanych pojawia się na powierzchniach wysoczyzn morenowych niż na powierzchniach sandrowych w obrębie tej samej strefy. Oczywiste jest, że sandry są formami młodszymi niż leżące w tym samym pasie równoleżnikowym wysoczyzny dennomorenowe, ale procesy korazyjne występowały na obu powierzchniach równocześnie. Należy również przyjąć, że procesy eolizacji na obszarze moreny dennej mogły rozpocząć się wcześniej niż na sandrach leżących w ich sąsiedztwie, ale nie można określić dystansu czasowego jaki różni te dwa okresy. 
Tabela 4. Zmienność wskaźnika wentyfikacji w układzie południkowym Table 4. Longitudinal variability of ventifaction index

\begin{tabular}{lcc}
\hline \multicolumn{1}{c}{ Strefa } & Wysoczyzny & Sandry \\
\hline Przedpole fazy leszczyńskiej & 37,9 & 35,7 \\
Zaplecze fazy leszczyńskiej & 36,1 & 31,5 \\
Przedpole fazy poznańskiej & 35,1 & 28,8 \\
Zaplecze fazy poznańskiej & 23,1 & 20,2 \\
Przedpole fazy pomorskiej & 12,1 & 8,9 \\
Zaplecze fazy pomorskiej & 0,8 & 0,02 \\
\hline
\end{tabular}

Jednak ten prosty wskaźnik też jest zależny od wielkości populacji wyjściowej, a więc populacji klastów, co jest istotne w dokonywaniu porównań na przykład wysoczyzn morenowych i sandrów, na których występują różne ilości głazów.

\section{TESTY ISTOTNOŚCI ZRÓŻNICOWANIA}

\section{Zróżnicowanie wewnątrzstrefowe}

Test $F$-Snedecora zastosowano w celu wykazania zróżnicowania między badanymi strefami morfologicznymi w zakresie zmienności populacji głazów eolizowanych. Jest to powszechnie stosowany test $\mathrm{w}$ badaniach przyrodniczych, a analizowane zbiory spełniają wszystkie zakładane dla jego zastosowania warunki odnoszące się do niezależności obserwacji, takich samych wartości wariancji i rozkładu normalnego lub quasi-normalnego badanych zmiennych. Użyteczność tego testu stwierdzono w badaniach zróżnicowania kierunków odpływu w Pradolinie Warszawsko-Berlińskiej (Antczak 1986).

Procedura matematyczna jest ogólnie znana i dostępna w większości podręczników do statystyki, dlatego tu przedstawiona zostanie w dużym skrócie. Jako zbiór próbek losowych potraktowano procentowy udział graniaków na poszczególnych polach testowych. Następnie testuje się kolejne hipotezy, które należy zweryfikować, dokonując oceny wariancji warunków międzypróbkowych i wewnątrzpróbkowych w celu stwierdzenia, czy te oceny wariancji są na tyle podobne, że różnice zachodzące między próbkami odzwierciedlają różnice zachodzące wewnątrz próbek. Przy dokonywaniu takiego porównania przyjmuje się hipotezę „zerową”, że nie ma żadnej istotnej różnicy pomiędzy badanymi próbkami, to znaczy że obie oceny wariancji nie są w sposób istotny różne. $\mathrm{Z}$ kolei po obliczeniu statystyki $F$-Snedecora, która jest ilorazem większej 
oceny wariancji i mniejszej oceny wariancji z tablic procentowego rozkładu $F$-Snedecora, odczytujemy procentowe prawdopodobieństwo, że różnica między próbkami nie jest wynikiem przypadkowego grupowania, a jakiejś istotnej różnicy pomiędzy badanymi zbiorami.

Zweryfikowano hipotezę, iż występuje istotna różnica pomiędzy polami testowymi położonymi w obrębie różnorodnych genetycznie powierzchni, ale w tej samej strefie morfologicznej. W tym celu wybrano losowo po 20 pól położonych na obszarach akumulacji glacjalnej i obszarach akumulacji fluwioglacjalnej w każdej ze stref i zastosowano dla nich test Snedecora. Według Gregory'ego (1976), liczba 20 pól jest wystarczająca do dokonania takiego porównania. Analizowano liczebność populacji graniaków na każdym z pól testowych w strefach przedpola i zaplecza kolejnych faz ostatniego zlodowacenia i oceniano wartość zróżnicowania wewnątrzstrefowego tych populacji. Wyniki tej oceny przedstawiono $\mathrm{w}$ tabeli 5 .

Tabela 5. Zróżnicowanie wewnątrzstrefowe populacji graniaków

Table 5. Intra-zonal differences in ventifact population

\begin{tabular}{lcccccc}
\hline $\begin{array}{l}\text { Strefa mor- } \\
\text { fologiczna }\end{array}$ & $\begin{array}{c}\text { Przedpole } \\
\text { fazy } \\
\text { leszczyń- } \\
\text { skiej }\end{array}$ & $\begin{array}{c}\text { Zaplecze } \\
\text { fazy } \\
\text { leszczyń- } \\
\text { skiej }\end{array}$ & $\begin{array}{c}\text { Przedpole } \\
\text { fazy } \\
\text { poznańskiej }\end{array}$ & $\begin{array}{c}\text { Zaplecze } \\
\text { fazy }\end{array}$ & $\begin{array}{c}\text { Przedpole } \\
\text { fazy } \\
\text { pomonkiej }\end{array}$ & $\begin{array}{c}\text { Zaplecze } \\
\text { fazy } \\
\text { pomomorskiej }\end{array}$ \\
\hline $\begin{array}{l}\text { Poziom } \\
\text { istotności }\end{array}$ & 0,19 & 0,12 & 0,17 & 0,23 & 0,16 & 0,13 \\
\hline
\end{tabular}

Zaobserwowane różnice są nieistotne statystycznie, gdyż każda z nich przekracza wartość 0,05 przyjętą jako wartość graniczną dla różnic statystycznie istotnych. Latem zróżnicowanie wewnątrzstrefowe nie jest istotne statystycznie i można dokonywać porównań międzystrefowych.

\section{Zróżnicowanie międzystrefowe}

Test $F$-Snedecora zastosowano również w celu wykazania zróżnicowania między badanymi strefami morfologicznymi w zakresie zmienności populacji głazów eolizowanych. Dla oceny istotności zróżnicowania badanych populacji przyjęto, jak dla większości zjawisk przyrodniczych, obszar prawdopodobieństwa 5\%. Oznacza to różnicę prawdopodobnie istotna, gdyż istnieje $95 \%$ prawdopodobieństwa, że badana różnica nie jest wynikiem przypadkowego grupowania, a istotnej różnicy pomiędzy zbiorami.

Test ten zastosowano dla poznania istotności różnic pomiędzy populacją głazów eolizowanych w obrębie horyzontów kamienistych, gdzie nie jest ona 
zmodyfikowana przez działanie człowieka i populacją głazów występujących na powierzchni w najbliższym sąsiedztwie tych horyzontów. W analizie statystycznej brano pod uwagę tylko populacje graniaków, ponieważ są to okazy, których rozpoznanie nie budzi wattpliwości, a ponadto w dotychczasowych opracowaniach używano ich dla badań statystycznych tej populacji. Dawało to więc możliwość dokonywania porównań. Analizie poddano zestaw stanowisk badawczych w strefie maksimum ostatniego zlodowacenia. Wartość statystyki $F$-Snedecora wynosiła dla tego obszaru $12 \%$, czyli różnica ta nie jest statystycznie istotna.

Kolejne zastosowania testu $F$ - Snedecora zmierzały do ustalenia istotności różnic pomiędzy częstotliwością występowania graniaków na:

1) polach testowych zlokalizowanych $w$ obrębie wysoczyzn gliniastych i obszarach akumulacji fluwioglacjalnej we wszystkich badanych strefach morfologicznych w celu określenia, czy zróżnicowanie wewnątrzstrefowe nie jest większe niż międzystrefowe

2) losowo wybranych polach testowych obszarów przedpola i zaplecza we wszystkich badanych strefach morfologicznych

3) powierzchniach akumulacji glacjalnej pomiędzy obszarami przedpola i zaplecza kolejnych stref morfologicznych.

Analogiczną analizę przeprowadzono dla obszarów akumulacji fluwioglacjalnej (tab. 6).

Tabela 6. Zróżnicowanie międzystrefowe populacji graniaków

Table 6. Inter-zonal differences In ventifact population

\begin{tabular}{lc}
\hline \multicolumn{1}{c}{ Różnice międzystrefowe } & Poziom istotności \\
\cline { 2 - 2 } Przedpole fazy leszczyńskiej i zaplecze fazy leszczyńskiej & 0,01 \\
Przedpole fazy leszczyńskiej i przedpole fazy poznańskiej & 0,01 \\
Zaplecze fazy leszczyńskiej i przedpole fazy poznańskiej & 0,05 \\
Zaplecze fazy leszczyńskiej i zaplecze fazy poznańskiej & 0,01 \\
Przedpole fazy poznańskiej i przedpole fazy pomorskiej & 0,05 \\
Zaplecze fazy poznańskiej i zaplecze fazy pomorskiej & 0,05 \\
\hline
\end{tabular}

$\mathrm{Z}$ wartości statystyk $F$-Snedecora, odniesionych do tablic prawdopodobieństwa, wynika, że różnice pomiędzy analizowanymi strefami w zakresie liczebności populacji graniaków są statystycznie istotne dla każdej analizowanej zależności. To zróżnicowanie na poziomie bardzo rygorystycznym, wynoszącym $99 \%$, zostało wykazane dla strefy maksimum przedpola i zaplecza ostatniego zlodowacenia oraz pomiędzy strefami przedpola wszystkich faz. Mniej rygorystyczny, ale również istotny statystycznie poziom zróżnicowania wynoszący 
0,05 wykazano dla różnic pomiędzy populacjami graniaków występującymi w strefie przedpola i zaplecza fazy poznańskiej oraz fazy pomorskiej.

Zmienność poziomu różnic międzystrefowych dla pól testowych położonych na powierzchniach wysoczyzn morenowych i sandrowych przedstawiono w tabeli 7 .

Tabela 7. Poziomy różnic międzystrefowych dla pól testowych położonych na powierzchniach wysoczyzn morenowych i sandrowych

Table 7. Level of Inter-zonal differences for the test plots situated on the surfaces of uplands and outwash plains

\begin{tabular}{lcc}
\hline & \multicolumn{2}{c}{ Poziom istotności } \\
\cline { 2 - 3 } \multicolumn{1}{c}{ Różnice międzystrefowe } & $\begin{array}{c}\text { wysoczyzny } \\
\text { morenowe }\end{array}$ & sandry \\
\hline Przedpole fazy leszczyńskiej i zaplecze fazy leszczyńskiej & 0,01 & 0,01 \\
Przedpole fazy leszczyńskiej i przedpole fazy poznańskiej & 0,01 & 0,01 \\
Zaplecze fazy leszczyńskiej i przedpole fazy poznańskiej & 0,01 & 0,05 \\
Zaplecze fazy leszczyńskiej i zaplecze fazy poznańskiej & 0,01 & 0,05 \\
Przedpole fazy poznańskiej i przedpole fazy pomorskiej & 0,05 & 0,05 \\
Zaplecze fazy poznańskiej i zaplecze fazy pomorskiej & 0,05 & 0,05 \\
\hline
\end{tabular}

Wszystkie przeanalizowane różnice są statystycznie istotne zarówno dla obszarów akumulacji glacjalnej, jak i fluwioglacjalnej, z tym że poziom istotności różnic statystycznych jest większy dla obszarów wysoczyzn morenowych, na których populacje graniaków są większe, niż dla obszarów sandrowych. Oznacza to, że nieuzasadnionym, z punktu widzenia statystycznego, byłoby przyjęcie wniosku, iż brak istotnych różnic pomiędzy polami testowymi położonymi w badanych strefach.

$\mathrm{Na}$ ostatnim etapie tej analizy dokonano obliczenia istotności zróżnicowania pomiędzy populacjami graniaków w obrębie poziomów terasowych w pradolinach za pomocą tego samego testu zróżnicowania funkcji $F$ dla obszarów pradolinnych (tab. 8).

Tabela 8. Istotność zróżnicowania populacji graniaków w pradolinach

Table 8. Significance of the variability of ventifact populations in pradolinas

\begin{tabular}{lc}
\hline \multicolumn{1}{c}{ Pradolina } & $\mathrm{F}$ \\
\hline Pradolina Baryczy i Pradolina Warszawsko-Berlińska & 0,01 \\
Radolina Baryczy i Pradolina Toruńsko-Eberswaldzka & 0,01 \\
Pradolina Warszawsko-Berlińska i Pradolina Toruńsko-Eberswaldzka & 0,05 \\
\hline
\end{tabular}

Wszystkie obliczone różnice okazały się istotne statystycznie, z tym że poziom zróżnicowania jest większy, bardziej rygorystyczny dla populacji 
graniaków pradoliny Baryczy i Pradoliny Warszawsko-Berlińskiej niż Pradoliny Toruńsko-Eberswaldzkiej. Fakt jest wynikiem zróżnicowania czasu trwania warunków klimatu suchego i zimnego, a więc peryglacjalnego na badanym obszarze. Podobnie jak w przedstawianych strefach, tutaj również bardziej istotne różnice występują pomiędzy pradolinami położonymi w południowej i centralnej Wielkopolsce, a mniej istotne - między pradolinami północnej i centralnej Wielkopolski.

\section{KORELACJE POMIĘDZY ZBIORAMI RÓŻNYCH TYPÓW GŁAZÓW EOLIZOWANYCH}

Chcąc ocenić, na ile zmiana $\mathrm{w}$ jednym $\mathrm{z}$ analizowanych zbiorów odzwierciedla się/lub nie w drugim zbiorze, zastosowano współczynnik korelacji według momentu iloczynowego, którego istotność statystyczną potwierdzono za pomocą testu $t$-Studenta. Zastosowanie tego współczynnika jest właściwe ze względu na zbadany charakter rozkładu analizowanych zmiennych. Już wartość odchylenia standardowego dla badanych populacji (tab. 2 i 3) wskazuje na ich dużą zmienność. W analizowanych zbiorach eologliptolitów brano pod uwagę współzależności wybranych podzbiorów:

Najbardziej istotny z badanych związków to wielkość populacji klastów i wielkość populacji eologliptolitów. Zależność ta wydaje się oczywista, ale istnieje cały szereg zmiennych, które ją warunkują. Im więcej głazów znajduje się na powierzchni, tym więcej z nich może ulec przeobrażeniu korazyjnemu, ale zapis tego procesu warunkują m.in.:

- kształt wyjściowy głazów na powierzchni poddanej działaniu wiatru. Im więcej głazów będzie miało ostre krawędzie, tym większa będzie szansa powstania graniaków na tej powierzchni;

- skład petrograficzny skał podłoża i odporność tych skał na wietrzenie warunkują pojawienie się i zachowanie rzeźby eolicznej w okruchu skalnym. Im więcej skał odpornych na wietrzenie znajduje się w podłożu, tym więcej głazów nie ulegnie degradacji wskutek procesu wietrzenia, a może zostać w nich zapisany proces korazji;

- czas oddziaływania wiatru na powierzchnię pokrytą odłamkami skalnymi. Im dłuższy jest ten okres, tym szansa powstania eologliptolitów z okruchów skalnych jest większa;

- rozkład uziarnienia osadów podłoża. Im więcej frakcji drobnopiaszczystej w podłożu, tym większa możliwość szlifowania wystających fragmentów skalnych;

- liczba wielograńców i trójgrańców zależy przede wszystkim od kształtu pierwotnego okruchów skalnych oraz liczby przemieszczeń klastów (obrotów), co umożliwia wystawienie kolejnych ścian - lic na działanie wiatru; 
- wreszcie kierunek i siła wiatrów nad tą powierzchnią, ich prędkość, zmienność kierunków i zdolność transportowa. Materiał korodujący to przede wszystkim piasek drobnoziarnisty transportowany w saltacji (Nowaczyk 2002) i trakcji (French 1976) oraz suspensji, na co wskazują eksperymentalne badania Dietricha (1977a, b) i potwierdzają badania terenowe Schlytera (1994).

Im więcej wiatrów wiejących $\mathrm{z}$ dużą prędkością $\mathrm{w}$ długich okresach, tym szansa zapisu w postaci rzeźby eolicznej głazów jest większa. Wiatry te muszą mieć znaczną prędkość, by unieść materiał szlifujący, a jedynie względnie stały kierunek działających wiatrów pozwala na zapis morfologiczny ich działania na okruchy skalne, co wykazują: Johnsson $(1958,1980)$, Schlyter $(1991,1995)$ i Svensson (1983, 1991 1992, 1996) oraz Vandenberghe i współpracownicy (1999). Duża zmienność kierunków wiatrów może spowodować powstanie jedynie mikrorzeźby eolicznej.

Wskazano niewątpliwie jedynie na część zmiennych warunkujących przebieg i zapis procesu korazji. Nie można zapomnieć również o procesach morfologicznych, zachodzących po zakończeniu korazji, a wpływających na możliwość zachowania zapisu morfologicznego tych procesów w postaci eologliptolitów - choćby procesy glebotwórcze. Jednak fakt pojawiania się pewnych prawidłowości $\mathrm{w}$ zakresie rozkładu badanych populacji w różnowiekowych strefach morfologicznych skłania do ich wyjaśnienia. Stwierdzenie, bądź nie, istnienia korelacji pomiędzy badanymi zmiennymi wskazuje na kierunek wypadkowej działania tych wszystkich zmiennych, natomiast nie pokazuje i nie wyjaśnia prostych zależności. Jednak poznanie i zbadanie tych wszystkich zależności jest poza problematyką pracy i nie zawsze możliwe przy obecnym stanie wiedzy. Istotnym problemem, na który zwracał uwagę Parysek (1982), jest autokorelacja czasowa i przestrzenna pomiędzy badanymi zmiennymi. $\mathrm{O}$ ile wśród zmiennych natury ekonomicznej zależność ta jest dość prosta do wykrycia i opisu statystycznego, to wśród zmiennych natury przyrodniczej nie można jej wykluczyć, ale możliwa jest do określenia dopiero po dokładnym rozpoznaniu fizycznej natury badanych procesów.

Powstaje zatem problem, czy stosowanie metod statystycznych dla poznania pewnych paleośrodowisk jest celowe? Prześledzenie zmienności zapisu procesu korazji w różnych strefach morfologicznych może wskazać, która $\mathrm{z}$ analizowanych zmiennych ma charakter dominujący. Dlatego dokonano obliczenia współczynników korelacji w obrębie wydzielonych różnowiekowych stref morfogenetycznych, rozróżniając wśród nich obszary akumulacji glacjalnej (gliniaste wysoczyzny morenowe) i fluwioglacjalnej (równiny piaszczysto-żwirowe).

Przeanalizowano następujące zależności pomiędzy:

1) wielkością populacji klastów i wielkością populacji eologliptolitów,

2) wielkością populacji klastów i graniaków,

3) wielkością populacji eologliptolitów i graniaków, 
4) całkowitą wielkością populacji graniaków i wielograńców, gdyż te ostatnie, według Dylika (1952), są kształtowane w wyniku procesu kongeliflukcji i mogą być traktowane jako jeden ze wskaźników złożonego, wielofazowego procesu formowania graniaków. Jak wskazywano, jest to pogląd dyskusyjny.

Obliczone współczynniki korelacji przedstawiono za pomocą tabeli 9.

Tabela 9. Wartości współczynników korelacji pomiędzy różnymi typami głazów w różnowiekowych strefach peryglacjalnych ostatniego zlodowacenia

Table 9. Coefficients of correlation among the various type of stone in Last-Glaciation periglacial zones of various ages

\begin{tabular}{lcccccccc}
\hline \multicolumn{1}{c}{ Strefa } & \multicolumn{1}{c}{$\begin{array}{c}\text { Klasty/ } \\
\text { eologliptolity }\end{array}$} & \multicolumn{2}{c}{$\begin{array}{c}\text { Klasty/ } \\
\text { graniaki }\end{array}$} & $\begin{array}{c}\text { Eologliptolity/ } \\
\text { graniaki }\end{array}$ & \multicolumn{2}{c}{$\begin{array}{c}\text { Graniaki/ } \\
\text { wielograńce }\end{array}$} \\
\hline Typ podłoża & glina & piasek & glina & piasek & glina & piasek & glina & piasek \\
\hline $\begin{array}{l}\text { Przedpole fazy } \\
\text { leszczyńskiej }\end{array}$ & 0,74 & 0,73 & 0,81 & 0,77 & 0,72 & 0,62 & 0,79 & 0.72 \\
$\begin{array}{l}\text { Zaplecze fazy } \\
\text { leszczyńskiej }\end{array}$ & 0,61 & 0,60 & 0,76 & 0,68 & 0,65 & 0,50 & 0,71 & 0,67 \\
$\begin{array}{l}\text { Przedpole fazy } \\
\text { poznańskiej }\end{array}$ & 0,62 & 0,58 & 0,63 & 0,59 & 0,63 & 0,56 & 0,76 & 0,66 \\
$\begin{array}{l}\text { Zaplecze fazy } \\
\text { poznańskiej }\end{array}$ & 0,53 & 0,50 & 0,56 & 0,51 & 0,55 & 0,51 & 0,62 & 0,58 \\
$\begin{array}{l}\text { Przedpole fazy } \\
\text { pomorskiej }\end{array}$ & 0,49 & 0,46 & 0,42 & 0,40 & 0,46 & 0,43 & 0,54 & $-0,29$ \\
$\begin{array}{l}\text { Zaplecze fazy } \\
\text { pomorskiej }\end{array}$ & 0,37 & 0,31 & 0,28 & 0,25 & 0,31 & 0,29 & 0,15 & $-0,13$ \\
\hline
\end{tabular}

$\mathrm{Z}$ analizy danych zawartych $\mathrm{w}$ tabeli 9 wynikają następujące wnioski:

1) Najbardziej istotne korelacje pomiędzy wielkością populacji klastów, eologliptolitów i wielograńców są typowe dla strefy przedpola i zaplecza fazy leszczyńskiej.

2) Silniejsze związki pomiędzy tymi populacjami pojawiają się na powierzchniach gliniastych niż na powierzchniach zbudowanych ze żwirów i piasków. Prawdopodobnie wynika to z co najmniej dwóch powodów:

a. większej ilości frakcji drobnoziarnistej, która decydowała o wydajności procesu korazji na powierzchniach gliniastych, jak to wykazano w rozdziałach analitycznych,

b. większej ilości eksponowanych głazów, które mogły być poddawane temu procesowi, 
Im dalej przesuwamy się ku północy, tym generalnie wartość współczynników korelacji maleje, co może wynikać z następujących faktów:

- krótszego czasu trwania warunków klimatycznych dogodnych dla działania procesu korazji, gdyż nie stwierdzono w tej strefie wyraźnego zmniejszenia populacji klastów czy zmiany uziarnienia osadów podłoża,

- wyraźnie ku północy maleje związek pomiędzy ilością graniaków i wielograńców, wartości współczynników korelacji wyraźnie zmniejszają się, a nawet przyjmują wartości ujemne, co świadczy o odwrotnej, a nie wprost proporcjonalnej zależności. Wartości te są jednak niewielkie i nie można ich interpretować jako znaczącej korelacji. Wynika to z faktu, że jednograniec jest najbardziej pierwotną formą graniaka, a ku północy maleje długość okresu trwania warunków peryglacjalnych i nie zdążyły się już wykształcić inne formy. Prawidłowość ta potwierdza się zarówno na obszarach akumulacji lodowcowej, jak i fluwioglacjalnej,

- coraz mniejsze zróżnicowanie w zakresie obliczonych współczynników korelacji na powierzchniach gliniastych i piaszczysto-żwirowych,

- mała wartość współczynnika korelacji pomiędzy wielkością populacji klastów i graniaków wskazuje na brak korelacji pomiędzy badanymi zbiorami. Wynika to z faktu, że każdy klast, który znalazł się na powierzchni, aby zostać eologliptolitem musiał być poddany jedynie działaniu wiatru, natomiast aby zostać przemodelowany do postaci graniaka musiał mieć również kształt pierwotny sprzyjający wypreparowaniu grani, a więc są to zależności złożone.

Wartość każdego ze współczynników testowano za pomocą testu $t$-Studenta. Każdorazowo było to prawdopodobieństwo wysoce istotne, a więc można przyjąć, że wnioski wynikające $\mathrm{z}$ analizy są wysoce prawdopodobne.

Prawie wszystkie $\mathrm{z}$ analizowanych współczynników wskazują że omawiane współzależności mają charakter złożony, co jest typowym zjawiskiem w przyrodzie i nie do końca opisują je proste zależności statystyczne.

Podstawowym celem pracy była próba wyjaśnienia, na ile warunki środowiska i czas trwania warunków peryglacjalnych determinują zmienność rozmieszczenia i cechy morfologiczne różnych postaci eologliptolitów. $Z$ analizy statystycznej wynika, że czas występowania warunków klimatycznych sprzyjających działaniu procesu korazji jest zmienną najistotniejszą.

Zastosowany zestaw metod statystycznych pozwolił na rozwiązanie postawionych problemów. Wskazał na dalsze możliwe kierunki badań zakresie korelacji wśród zmiennych determinujących rozwój populacji eologliptolitów. 


\section{PRZYCZYNY ZRÓŻNICOWANIA POPULACJI GŁAZÓW EOLIZOWANYCH NA RÓŻNOWIEKOWYCH OBSZARACH PERYGLACJALNYCH}

\section{Zmienność populacji graniaków w przekroju południkowym}

Analiza zmienności populacji eologliptolitów i graniaków na wysoczyznach morenowych i sandrach różnego wieku w zasięgu ostatniego zlodowacenia pozwoliła rozwiązać problem, na ile czas warunków peryglacjalnych decyduje o liczebności populacji tych głazów (tab. 10).

Tabela 10. Częstotliwość występowania eologliptolitów w przekroju południkowym Table 10. Longitudinal frequency of occurence of wind-polished stones

\begin{tabular}{lcccc}
\hline & \multicolumn{2}{c}{ Powierzchnie morenowe } & \multicolumn{2}{c}{ Powierzchnie sandrowe } \\
\cline { 2 - 5 } & eologliptolity & graniaki & eologliptolity & graniaki \\
\hline Przedpole fazy leszczyńskiej & 52,3 & 46,1 & 56,6 & 33,7 \\
Zaplecze fazy leszczyńskiej & 44,5 & 36,2 & 39,7 & 29,8 \\
Przedpole fazy poznańskiej & 40,0 & 26,1 & 35,1 & 23,1 \\
Zaplecze fazy poznańskiej & 32,3 & 24,5 & 28,8 & 20,2 \\
Przedpole fazy pomorskiej & 18,5 & 12,1 & 14,9 & 8,9 \\
Zaplecze fazy pomorskiej & 2,2 & 0,8 & 1,6 & 0,0 \\
\hline
\end{tabular}

Z przedstawionego zestawienia wynika, że wskaźnik występowania głazów eolizowanych na polu testowym $\mathrm{w}$ ujęciu procentowym jest również istotną miarą ukazującą zróżnicowanie regionalne tego zjawiska. Oczywiście jest to wartość średnia i im bardziej badane zmienne są zróżnicowane, tym jest to wartość bardziej zafałszowana, ale generalna prawidłowość pojawia się i w tym prostym zestawieniu. Można więc stwierdzić, że jest to dodatkowe potwierdzenie zaobserwowanej prawidłowości. Potwierdzone statystycznie zróżnicowanie częstotliwości występowania eologliptolitów i graniaków na powierzchniach zarówno gliniastych, jak i piaszczysto-żwirowych oraz terasach w pradolinach wskazuje, że proces korazji działał na wszystkich powierzchniach eksponowanych na wiatr, niezależnie od ich genezy.

Wśród rozważanych wskaźników pojawił się również wskaźnik ,wentyfikacji”, wyrażający się ilorazem procentowej wielkości populacji graniaków i eologliptolitów dla badanych populacji (tab. 4). Iloraz ten wykazuje generalną tendencję wzrostu w kierunku południowym, ale nie jest to prawidłowość, gdyż w strefie fazy pomorskiej ulega ona zakłóceniu. Wynika to prawdopodobnie z faktu powszechnej dostępności świeżej peryglacjalnej ostrokrawędzistej 
zwietrzeliny w tej strefie, która potencjalnie, mimo zmniejszonych populacji, ulegała eolicznemu przekształceniu do postaci graniaków.

Przyjmując, że eologliptolity są pierwotną formą graniaka, choć nie każdy eologliptolit ulega przekształceniu $\mathrm{w}$ graniak $\mathrm{i}$ jest to założenie uproszczone, można zauważyć, że wypadkowa procesów kształtujących głazy graniaste zmienia się strefowo. Optymalne warunki dla powstania form graniastych występowały na przedpolu fazy leszczyńskiej ostatniego zlodowacenia, co wynikało zarówno z długiego okresu oddziaływania klimatu peryglacjalnego, jak i warunków panujących w tej strefie, określanych przez Kozarskiego (1995) jako pustynia arktyczna. Założone uproszczenie polega na tym, że każdy klast, niezależnie od swojego kształtu pierwotnego, może stać się graniakiem. Jest ono prawdziwe jedynie częściowo, gdyż prawdopodobnie jedynie klast o pierwotnych kształtach ostrokrawędzistych może stać się graniakiem. Nie udało się dotychczas udowodnić, że zmiana położenia głazu w stosunku do dominującego kierunku wiatru zawsze prowadzi do wykształcenia kolejnej grani, choć Sharp (1964) i Laity (1987) wskazują na taką możliwość. W kształtowaniu wielograńców istotną rolę zapewne odgrywa wielofazowość cykli korazyjnych.

\section{Zróżnicowanie przestrzenne składu petrograficznego graniaków}

W pracy Antczak-Górki (2005) przedstawiono prosty podział petrograficzny skał, w których znajdowano graniaki na obszarach testowych Wielkopolski. Analiza tej cechy wykazała, że przede wszystkim odporność skał na wietrzenie decyduje o ukształtowaniu i zachowaniu cech graniaków, a skład mineralny oraz tekstura tych skał decydują o mikrorzeźbie i kierunku rozwoju pojedynczych okazów. Zmienność petrograficzną graniaków w badanych strefach morfologicznych przedstawia za pomocą tabeli 11 .

Zestawienie to ukazuje, że nie ma znaczącego zróżnicowania pomiędzy kolejnymi strefami w zakresie petrografii. Oznacza to, że nie tyle zróżnicowanie petrograficzne glin i osadów fluwioglacjalnych w poszczególnych strefach morfologicznych decyduje o liczebności tych populacji, ile liczebność populacji rozkruszonych skał w środowisku glacjalnym oraz ich podatność na działanie korazji i odporność na wietrzenie. We wszystkich analizowanych strefach dominują graniaki wykształcone $\mathrm{w}$ porfirach i piaskowcach, co jest zgodne z dotychczas publikowanymi spostrzeżeniami Nitza (1965) i Kubiś (1978) z obszaru Niżu Europejskiego. Również w opracowanich Karlova (1966) oraz Schlytera (1991, 1992, 1995) stwierdzono dominację tych typów skał wśród graniaków, lecz na obszarach Skanii znacznie większe ilości graniaków pojawiają się wśród kwarcytów, co wynika z lokalnego składu petrograficznego skał podłoża. 
Tabela 11. Zmienność petrograficzna graniaków peryglacjalnych w Polsce Zachodniej Table 11. Petrographic variability of ventifacts in Western Poland

\begin{tabular}{lccc}
\hline \multirow{2}{*}{ Rodzaj skały } & \multicolumn{3}{c}{ Faza } \\
\cline { 2 - 4 } & leszczyńska & poznańska & pomorska \\
\hline Porfiry & 31,2 & 34,3 & 32,9 \\
Piaskowce & 33,9 & 27,8 & 28,9 \\
Kwarcyty & 8,4 & 15,2 & 16,0 \\
Granity & 7,3 & 6,9 & 6,1 \\
Gnejsy & 6,0 & 4,9 & 4,2 \\
Diabazy & 2,9 & 3,2 & 3,7 \\
Granitognejsy & 4,3 & 3,6 & 2,3 \\
Lidyty & 2,1 & 1,2 & 0,0 \\
Dioryty & 3,6 & 2,9 & 5,2 \\
Wapienie & 1,3 & 0,0 & 0,7 \\
\hline
\end{tabular}

\section{WNIOSKI}

Przedstawiona analiza zmienności ilościowej i przestrzennej rozmieszczenia populacji głazów eolizowanych w zachodniej Polsce obejmowała obszar objęty zlodowaceniem warty (Kotlina Szczercowska, Wysoczyzna Kaliska, Wysoczyzna Turecka) oraz kolejne strefy przedpola i zaplecza faz leszczyńskiej, poznańskiej i pomorskiej aż po subfazę wolińską ostatniego zlodowacenia. Głazy rzeźbione przez wiatr najstarszej z analizowanych stref stanowią ponad $60 \%$ całej populacji klastów, a graniaki ponad 50\%. Znaczna (ok. 40\%) część zbioru graniaków to wielograńce. Tak liczna populacja eologliptolitów może być rezultatem jednej lub kilku faz procesów korazyjnych. Można założyć, że oprócz eolizacji związanej z fazą deglacjacji stadiału warty zlodowacenia środkowopolskiego głazy występujące w tej strefie mogły być eolizowane we wcześniejszych fazach zlodowacenia środkowopolskiego (przy założeniu redepozycji eologliptolitów), jak również w późniejszych cyklach przeobrażenia w warunkach pustyni arktycznej.

Kamienie eolizowane, w tym graniaki, występujące na południe od strefy maksimum ostatniego zlodowacenia występują w większych populacjach zarówno na powierzchni, jak i w fosylnych horyzontach deflacyjnych oraz wykazują cechy większej dojrzałości niż na północ od tej strefy. Głazy te występują powszechnie zarówno na powierzchniach akumulacji glacjalnej, jak i fluwioglacjalnej oraz w obrębie teras w pradolinach, co jest dowodem na klimatyczne, a nie litologiczne uwarunkowanie ich powstawania. Niezależnie od typu litologicznego powierzchni, jeżeli występowała na niej frakcja kamienista, była ona eolizowana, a zapis tego procesu może być zróżnicowany. 
Oprócz czasu trwania warunków peryglacjalnych o liczebności populacji głazów eolizowanych decyduje przede wszystkim typ genetyczny podłoża. Nie można porównywać populacji tych głazów, nie znając genezy powierzchni, na której je zidentyfikowano. Na powierzchniach akumulacji glacjalnej (glinach i glinach z pokrywą piasków ablacyjnych) występują większe o kilka do kilkunastu procent populacje eologliptolitów, w tym również graniaków. Wynika to $\mathrm{z}$ większej liczby głazów na tych powierzchniach i to głazów o kształtach ostrokrawędzistych, co jest rezultatem charakteru transportu glacjalnego (Boulton 1978) oraz dostępności drobnopiaszczystej frakcji koradującej.

Na powierzchniach akumulacji fluwioglacjalnej populacje głazów eolizowanych są mniejsze, a formy graniaków są mniej skomplikowane - głównie jednograńce $z$ jedną lub dwoma oszlifowanymi ścianami. Nie można się zgodzić ze skrajnym poglądem Nitza (1965), że graniaki na sandrach pojawiają się jedynie jako głazy redeponowane, bo znane są ich liczne stanowiska na takich powierzchnich (Hobbs 1931; Jewtuchowicz 1955; Stankowski 1963; Lindsay 1973; Kubiś 1978; Krüger 1994 i in.). Część z głazów występujących w osadach fluwioglacjalnych może pochodzić z procesu redepozycji, czego dowodem są eologliptolity rozproszone w piaskach i żwirach Międzyrzecza Warciańsko-Noteckiego. Potwierdzeniem tego wniosku jest obecność w tych osadach graniaków dwustronnych, co według Dylika (1952), Sharpa $(1964,1980)$ i Laity (1987) jest dowodem na zmianę pierwotnej pozycji graniaków. Może to być redepozycja zarówno w obrębie środowiska fluwioglacjalnego, jak i redepozycja związana z wtórnym transportem, na przykład frakcja kamienista ukształtowana w środowisku glacjalnym może znaleźć się wśród osadów fluwioglacjalnych.

Kolejną istotną zmienną warunkującą liczebność populacji głazów eolizowanych jest morfologia terenu. Nie można jednak przyjąć sugestii Dylika (1952), że powstanie złożonych form graniaków związane jest jedynie z procesem kongeliflukcji i ten proces decyduje o liczebności populacji graniaków w obrębie różnych części stoku. Podstawowe znaczenie, jak wykazano w cytowanym artykule, ma również litologia powierzchi stokowych. Badania Kubiś (1978) i Antczak-Górki (2005) roku wykazały, że ekspozycja stoku nie ma istotnego wpływu na liczebność populacji głazów eolizowanych, co może sugerować kształtowanie tych głazów w wielu fazach, w których kierunek wiatru ulegał zmianie. Problem ten wymaga dalszych studiów.

W każdej z analizowanych stref zaobserwowano różnicę wielkości populacji głazów eolizowanych pomiędzy strefą przedpola i zaplecza. Największe zmiany, potwierdzone statystycznie, występują między przedpolem i zapleczem fazy leszczyńskiej oraz fazy pomorskiej (tab. 10). Prawdopodobnie wynika to z niewielkiego czasowego dystansu pomiędzy fazą leszczyńską i poznańską. W strefie przedpola i zaplecza fazy poznańskiej populacja głazów eolizowanych ulega zmniejszeniu i pojawia się coraz więcej prostych form graniaków (jednograńców). Zróżnicowanie pomiędzy wielkością populacji różnych typów 
eologliptolitów w strefie przedpola fazy leszczyńskiej i poznańskiej zostało również potwierdzone statystycznie.

Zarówno na przedpolu, jak i zapleczu fazy leszczyńskiej populacje głazów eolizowanych są znaczne (ok. 60\%), natomiast w kierunku północnym, szczególnie w strefie pomiędzy fazą poznańską i pomorską, obserwuje się ich gwałtowny zanik. Jest to potwierdzenie tezy o paleogeograficznej wymowie populacji graniaków. Ilość eologliptolitów i graniaków na polach testowych maleje ku północy (ryc. 2), zarówno na powierzchniach akumulacji glacjalnej, jak i fluwioglacjalnej. Jest to jednocześnie funkcja czasu, gdyż obszary późniejszej deglacjacji krócej podlegały działalności procesów eolicznych, jak i zmiany warunków klimatycznych środowiska, które od pustyni arktycznej przeobrażały się $\mathrm{w}$ warunki tundry trawiasto-krzewiastej $\mathrm{w}$ czasie górnego plenivistulianu

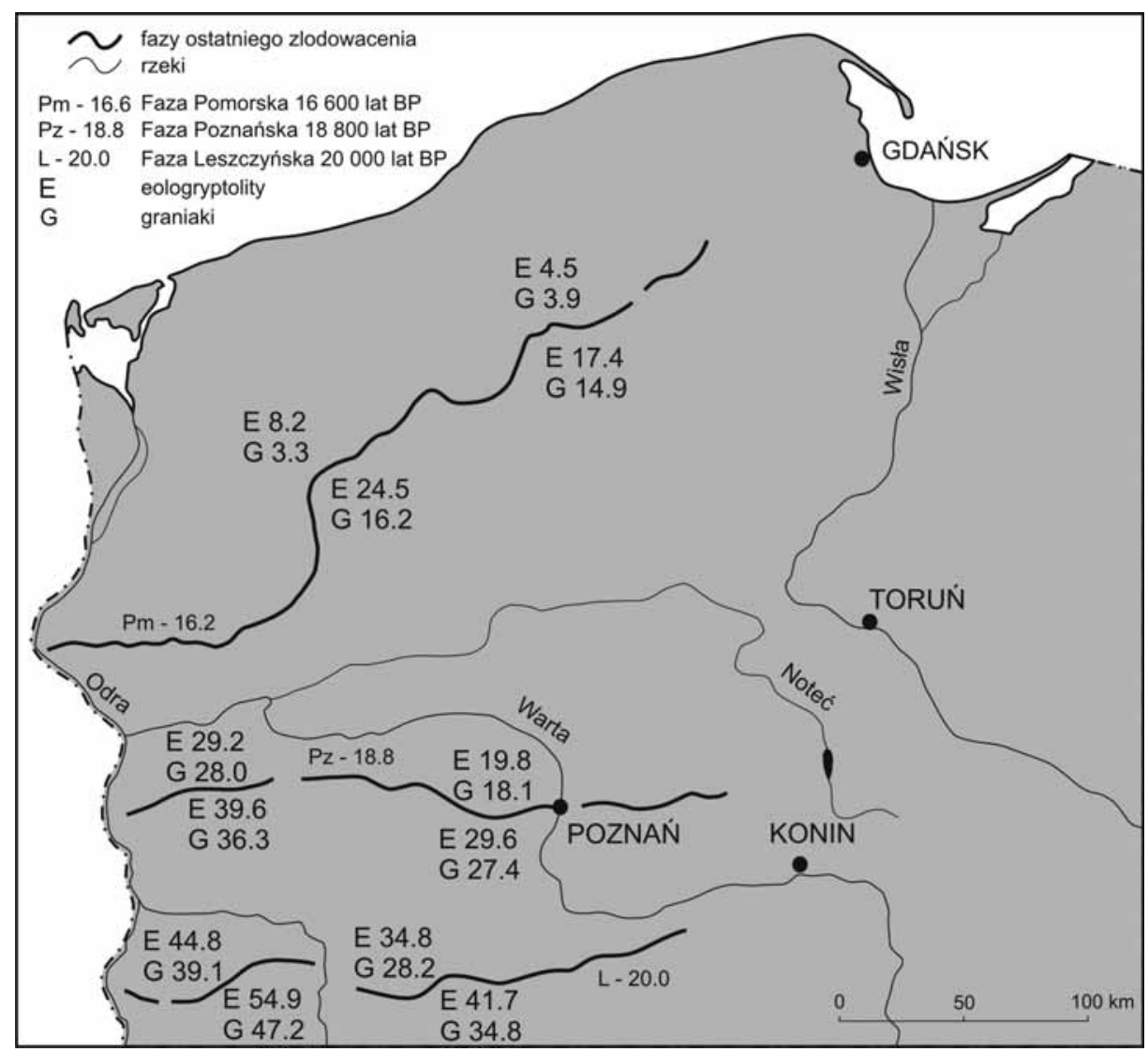

Ryc. 1. Zmienność populacji głazów eolizowanych (w procentach) w strefach przedpola i zaplecza kolejnych faz ostatniego zlodowacenia (wiek faz wg Kozarskiego, 1995)

Fig. 1. Variability of the population of ventifacts and wind-polished stones in succesive zones of the last glaciation (the age of the baltic glaciation phases, after Kozarski, 1995) 


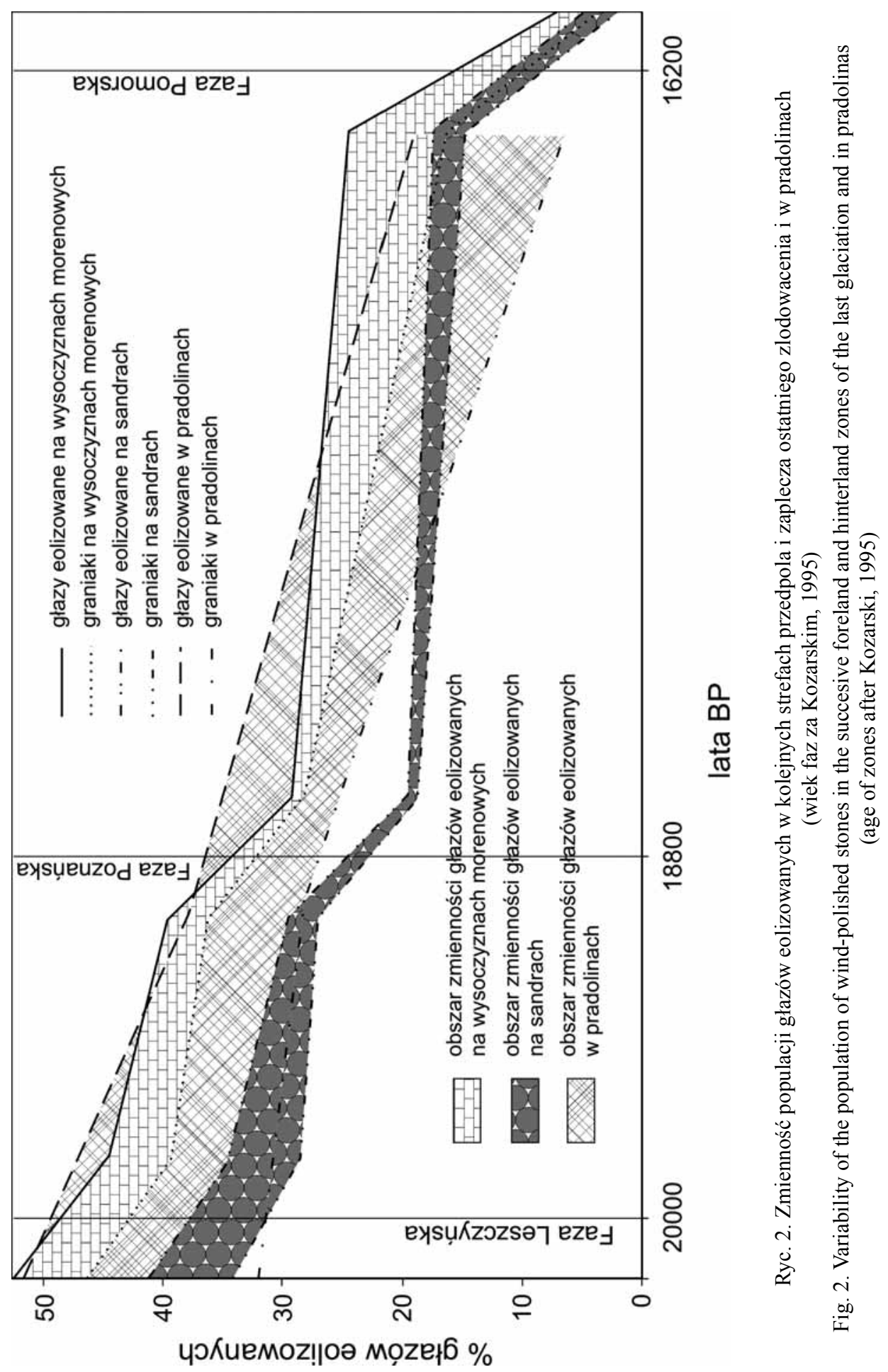


i tundry parkowej w początkach późnego vistulianu - w drugiej połowie najstarszego dryasu, böllingu i w starszym dryasie (Kozarski 1995). Taki obraz zmienności szaty roślinnej w późnym glacjale dla północno-zachodnej Polski przedstawił w swoich opracowaniach Tobolski (1966) oraz Wasylikowa (1964) dla Polski Środkowej. Intensywność procesów deflacji i korazji była hamowana przez gęstniejącą szatę roślinną, co stwierdzili Greeley i Iverson (1985), Kozarski (1995) oraz wielu innych.

Na północ od strefy zasięgu fazy pomorskiej eologliptolity występują jedynie jako pojedyncze okazy, a nie w postaci skupisk, podobnie jak na terenie Niemiec (Nitz 1965; Krausse 1966). Jest to wzmocnienie wniosku o zasadniczej roli funkcji czasu w eolizowaniu klastów.

Graniaki są zjawiskiem typowym dla klimatu suchego, a na terenie Europy specyficznej odmiany tego klimatu - klimatu peryglacjalnego. Mogą one, ze strukturami szczelin mrozowych z pierwotnym wypełnieniem mineralnym, być dowodem na znaczną suchość klimatu górnego plenivistulianu, który nie sprzyjał rozwojowi szaty roślinnej i stwarzał dogodne warunki dla intensywnego działania korazji i innych procesów eolicznych. Graniaki mogą więc być uznawane za ważny wskaźnik paleośrodowiskowy.

Większość datowań piasków pokrywowych zalegających na fosylnych horyzontach kamienistych z graniakami (Meyer 1986; Jörgenssen 1988) wskazuje, że powstały one w okresie górnego plenivistulianu oraz późnego vistulianu. Proces formowania graniaków zachodził jeszcze w klimacie półsuchym późnego vistulianu, gdyż najmłodsze graniaki pochodzą ze starszego dryasu (Kozarski, Nowaczyk 1991). Pierwsza faza deglacjacji ostatniego zlodowacenia cechowała się klimatem bardzo zimnym i suchym, czego dowodem są liczne struktury wieloboków szczelin mrozowych oraz duże populacje graniaków występujące również w tych samych seriach sedymentacyjnych, co wykazano w stanowisku Radomierz (Antczak-Górka 1998). Graniaki wchodzą w skład osadów wypełniających kliny zmarzlinowe z pierwotnym wypełnieniem mineralnym - potwierdza to wniosek o ich klimatycznej wymowie.

\section{LITERATURA}

Antczak B., 1986: Transformacja układu koryta i zanik bifurkacji Warty w Pradolinie Warszawsko-Berlińskiej i południowej części przełomu poznańskiego podczas późnego vistulianu. Wyd. Nauk. UAM, Poznań.

Antczak-Górka B., 1998: Climatic conditions of the last ice-sheet decay in the light of corrasion processes studies in southern Wielkopolska. [W:] W. Schirmer (red.), Dunes and fossil soils, $55-61$.

Antczak-Górka B., 1999: Wind-polished stones within the maximum limit of the vistulian ice-sheet in southern Great Poland Lowland, Biul. Perygl., 38, 63-72.

Antczak-Górka B., 2005: Glazy rzeźbione przez wiatr jako wskaźniki różnowiekowych stref peryglacjalnych ostatniego zlodowacenia w Polsce Zachodniej, Wyd. Nauk. UAM, Poznań. 
Boulton G.S., Paul M.A., 1976: The influence of genetic processes on the geotechnical properties of glacial tills, QJ. Engng. Geol., Vol. 9, 159-194.

Christianssen H.H., Svensson H., 1998: Wind-polished boulders as indicators of Late Weichselian wind regime in Denmark in relation to neighbouring areas, Permafrost and Periglacial Processes, Vol. 9, 1-21.

Christianssen H.H., Svensson H., 1999: Windpolish evidence: An important Direct Indicator of Geomorphologically Active paleo- winds, Permafrost and Periglacial Processes, Vol. 10, No. 2, 203-205.

Dietrich R.U., 1977a: Impact abrasion of harder by softer materials. Journ. of Geol., Vol. 85, 242-246.

Dietrich R.U., 1977b: Wind erosion by snow, Journ. of Glaciology, Vol. 18, 148-149.

Dylik J., 1952: Głazy rzeźbione przez wiatr i utwory podobne do lessu w środkowej Polsce, Biul. Inst. Geol., 67, 231-332.

Dylikowa A., 1967: Wydmy środkowopolskie i ich znaczenie dla stratygrafii schytkowego plejstocenu. [W:] R. Galon, J. Dylik (red.), Czwartorzęd Polski, PWN, Warszawa, 353-371.

French H.M., 1976: The Periglacial Environment, Longman, London and New York, 1-309.

Gregory S., 1976: Metody statystyki w geografii, PWN, Warszawa.

Hobbs W., 1931: Loess, pebble bands and boulder from glacial outwash of the Greenland continental glacier, Journ. of Geol., Vol. 39.

Isarin R.F.B., Renssen H., Koster E.A., 1997: Surface wind climate during Younger Dryas in Europe as inferred from aeolian records and model simulations, Paleogeography, Paleoclimatology, Paleoecology, Vol. 134, 127-148.

Jewtuchowicz S., 1955: Struktura sandru, Act. Geogr. Univ. Lodz., Vol. 5, 30-42.

Johnsson G., 1958: Periglacial wind and frost erosion at Klagerup S.W. Scania, Geografiska Annalers, Vol. 40(3-4), 232-243.

Johnsson G., 1980: Periglacial wind and frost erosion at Klagerup, SW Scania, Geogr. Annal., Vol. 40, 232-243.

Jörgenssen M., 1988: TL dated Weichselian deflation surfaces from Northern Jutland, Denmark Norsk Geogr. Tiolsskrift, Vol. 42, 225-229.

Karlov N.N., 1966: A new classification of eologlyptopiths, Biul. Peryglacjalny, 19, 221-230.

Kozarski S., 1990: Pleni- and late Vistulian aeolian phenomena In Poland: New occurences, paleoenvironmental and stratigraphical interpretation, Act. Geogr. Debrecina, Vol. 26/27, 31-45.

Kozarski S., 1995: Deglacjacja pólnocno-zachodniej Polski: warunki środowiska i transformacja geosystemu, Dok. Geogr. IG PAN, nr 1, 1-82.

Kozarski S., Nowaczyk B., 1991: Lithofacies variation and chronostratigraphy of Late Vistulian and Holocene aeolian phenomena in northwestern Poland. Zietschr. für Geomorph., Suppl., bd. 90, 107-122.

Krüger J., 1994: Glacial processes, sediments., Landforms and stratigraphy in the terminus region of Myrdalsjökul, Iceland, Fol. Geogr. Donica, Vol. 21.

Kubiś W., 1978: Próba wykorzystania graniaków jako prawdopodobnego wyznacznika pótnocnego zasięgu strefy peryglacjalnej w petni Würmu między Turkiem a Koninem, Bad. Fizjogr. nad Polską Zach., t. 31, Geogr. Fiz., 103-126.

Laity J.E., 1987: Topographic effects on ventifact development, Mojave. Desert. California, Physical Geogr., Vol. 8, No. 2, 113-132.

Lindsay J.F., 1973: Venifacts evolution in Wright Valley, Antarctica, Geol. Soc. of America Bull., Vol. 84, 1791-1797.

Meyer H.-H., 1989: Paläowind Indikatoren - Möglichkeiten, Grenzen und Probleme ihrer Auvendung am beispiel des Weichsel - Hohglazials in Europa, Mitteilnugen aus dem Geologischen Institut der Universitat Hannowver, 1-61.

Nitz B., 1965: Windgeschliffene Geschiebe und Steinsohlen zwischen Fläming und Pommerscher Eisrandlage, Geol., Vol. 14, Heft 5/6, 686-698. 
Norcliffe G.B., 1986: Statystyka dla geografów, PWN, Warszawa.

Nowaczyk B., 1976: Geneza i rozwój wydm śródladowych w zachodniej części Pradoliny Warszawsko-Berlińskiej w świetle badań struktury, uziarnienia i stratygrafii budujacych je osadów, Pr. Kom. Geogr.-Geol. PTPN, nr 16, 1-108.

Nowaczyk B., 1986: Wiek wydm, ich cechy granulometryczne i strukturalne a schemat cyrkulacji atmosferycznej w Polsce w późnym vistulianie i holocenie, Wyd. Nauk. UAM, Poznań, 1-245.

Nowaczyk B., 2002: Litologiczny i morfologiczny zapis działalności wiatru w Polsce w ostatnich 30 tysiacach lat, Czas. Geogr., nr 73(4), 275-331.

Rotnicki K., 1970: Glówne problemy wydm śródladowych w Polsce w świetle badań wydmy w Weglewicach, Pr. Kom. Geogr.-Geol. PTPN, Vol. 11(2), 1-14.

Schlyter P., 1991: Recent periglacial wind action in Scania and adjacent areas of S. Sweden, Zeitschr. für Geomorph. N.F. Suppl. - Band 90, 143-153.

Schlyter P., 1992: Large sorted stone polygons and ventifact distribution in the Syrkadel Area, Scania, S. Sweden, Geogr. Annal., Ser. A, Vol. 74, 219-226.

Schlyter P., 1995: Ventifacts as paleo- wind indicator in southern Scandinavia, Permofrost and Periglacial Processes, Vol. 6, 207-219.

Sharp R.P., 1964: Wind-driven sand in Coachello Valley, California, Geol. Soc. of America Bull., Vol. 75, 785-804.

Sharp R.P., 1980: Wind-driven sand in Caachello Valley, California. Further data, Geol. Soc. of America Bull., Vol. 91, 724-730.

Svensson H., 1991: Windabrasion i fast berg under högsta kustlinjen i södra Holland [Enp: Wind abrasion in solid rocks below the highest Late Weichselian shoreline in Southern Holland, the Swedish west coast.], Svensk. Geogr. Arsbok Vol. 67, 157-167.

Svensson H., 1992: Wind-blasted erratics in Southern Sweden. [W:] K. Billwitz, F. Jäger, W. Janke (red.), Jungquastäre Landschaftsträume, Springer, Berlin, 105-109.

Svensson H., 1993: Hunnsberget, a hill in southwestern Sweden with well presented wind-cutting on eratics, Swensk Geogr. Ärsbok, Vol. 69, 107-114.

Svensson H., 1996: Wind from the past revealed on stones, Forsknig og Framsteg, Vol. 3, 18-19.

Tobolski K., 1966: Późnoglacjalna i holoceńska historia roślinności na obszarze wydmowym w dolinie środkowej Prosny, PTPN, Pr. Kom. Biol. Vol. 32, z. 1, 1-69.

Vandenberghe J., Huissteden J., 1988: Fluvio-aeolian interactions in a region of continuos permafrost. [W:] Permafrost V-th International Conference, Vol. 1 Ed. Kaare Seuneset, Norway, Tapir Publishers, 876-881.

Wasylikowa K., 1964: Roślinność i klimat późnego glacjału w środkowej Polsce na podstawie badań w Witowie koto Łęczycy, Biul. Perygl., nr 13, 261-376. 